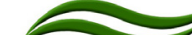

\title{
Heavy metals bioaccumulation in fish of southern Iran and risk assessment of fish consumption
}

\author{
Mohammad Malakootian $^{1^{*}}$, Mohammad Seddiq Mortazavi², Abdolkarim Ahmadi ${ }^{3}$ \\ ${ }^{1}$ Professor, Environmental Health Engineering Research Center, Department of Environmental Health, School of Public Health, Kerman \\ University of Medical Sciences, Kerman, Iran \\ ${ }^{2}$ Associate Professor, Persian Gulf and Oman Sea Ecological Research Institute, IFSRI, AREEO, Bandar Abbas, Hormozgan, Iran \\ ${ }^{3} \mathrm{MSc}$, Department of Environmental Health, School of Public Health, Kerman University of Medical Sciences, Kerman, Iran
}

\begin{abstract}
Background: This study purposed to assess the health risks of heavy metals including nickel $(\mathrm{Ni})$, chromium $(\mathrm{Cr})$, mercury $(\mathrm{Hg})$, and lead $(\mathrm{Pb})$ in three widely-consumed fish from the coast of Bandar Abbas (Persian Gulf) and to determine the maximum amounts allowed for consumption according to the degree of contamination.

Methods: This cross-sectional study was conducted in the summer and fall of 2013. Thunnus tonggol and Liza klunzingeri were selected from the Bandar Abbas market, and Pleuronectiformes were caught from the sea. Heavy metal concentrations were determined by atomic absorption. Risk assessment and allowable consumption levels were determined according to methods provided by the US Environmental Protection Agency (USEPA).

Results: The highest average levels of $\mathrm{Ni}$ and $\mathrm{Cr}$ in Thunnus tonggol were 0.059 and $0.234(\mu \mathrm{g} / \mathrm{g}$ dry weight), respectively. The highest average level of $\mathrm{Hg}$ in Pleuronectiformes was 0.095 ( $\mu \mathrm{g} / \mathrm{g}$ dry weight), and the highest average level of $\mathrm{Pb}$ in Liza klunzingeri was 0.006 ( $\mu \mathrm{g} / \mathrm{g}$ dry weight). The target hazard quotient (THQ) for all analyses of metals in the studied species and the hazard index (HI) were less than 1 for all three species.

Conclusion: The results showed that despite $\mathrm{Ni}, \mathrm{Cr}, \mathrm{Hg}$, and $\mathrm{Pb}$ pollution, the consumption of up to 4 $(\mathrm{kg} / \mathrm{d})$ of Thunnus tonggol by adults and up to $2.2(\mathrm{~kg} / \mathrm{d})$ by children does not cause health problems in terms of the tested heavy metals. For Liza klunzingeri, these levels are 7.32 and $4.02(\mathrm{~kg} / \mathrm{d})$, respectively. Keywords: Nickel; Chromium; Mercury; fish; Risk assessment.

Citation: Malakootian M, Mortazavi MS, Ahmadi A. Heavy metals bioaccumulation in fish of southern Iran and risk assessment of fish consumption. Environmental Health Engineering and Management Journal 2016; 3(2): 61-68. doi: 10.15171/EHEM.2016.02.
\end{abstract}

Article History:

Received: 27 January 2016 Accepted: 11 May 2016 ePublished: 30 May 2016

\section{Introduction}

The presence of heavy metals in the environment is a cause for major concern. Even at low concentration levels, they can cause problems as a result of toxicity and their tendency to permeate the food chain (1). The term 'heavy metals' refers to metals whose specific gravity is greater than $5 \mathrm{~g} / \mathrm{cm}^{3}$ in their standard state (2). These metals penetrate aquatic ecosystems through agricultural effluents and discharged industrial wastewater which have different chemical compounds, including heavy metals (3). Fish accumulate metals by ingesting particulate material suspended in water, through food, through the ion-exchange of dissolved metals across lipophilic membranes (e.g., the gills), and through adsorption onto tissue and membrane surfaces (4). Fish are considered bio-indicators of the quality of ecosystems because of their ability to bioconcentrate and integrate a contaminant load (5).
According to statistics compiled by Food and Agriculture Organization (FAO), the consumption of fish accounts for $16 \%$ of animal protein consumed and $6 \%$ of total protein intake by people of the world (6). Having high levels of unsaturated fats and low cholesterol and being high in protein makes fish one of the most important sources of protein. It is considered an important food ingredient in many countries, including Iran, and its production is increasing (7).

Heavy metals may enter the human body through the consumption of fish and thereby create a serious health hazard (8). The measurement of heavy metals in fish can be useful to assessing potential health risks to humans associated with the consumption of fish (9).

Health risk assessment is defined by the US Environmental Protection Agency (USEPA) as the description of the potential adverse health effects of humans as a result of 
exposure to contaminants (10).

Because of the importance of measuring heavy metal concentrations in fish and assessing the health risk associated with exposure to heavy metals through the consumption of fish, the accumulation of heavy metals in fish has been widely studied throughout the world (3,11-13). Furthermore, numerous studies have evaluated potential health risks associated with exposure to heavy metals through fish consumption $(7,9,14-17)$.

The present study was undertaken to determine the levels of heavy metals in the three most frequently used fish caught from Bandar Abbas waters. As a result of this study, consumers and authorities can become better aware of the possible risks of contamination through daily intake of fish.

\section{Methods}

This cross-sectional study was conducted in the summer and fall of 2013. Sampling was conducted on three of the most widely consumed fish caught from the coast of Bandar Abbas, i.e. Thunnus tonggol, Pleuronectiformes (Pseudorhombus elevatus and Euryglossa orientalis), and Klunzinger mullet that were being sold at the town market or were caught directly from the sea. Five samples from each fish species were tested three times at 2-month intervals (overall 15 samples for each fish species). A total of 180 tests were conducted on the samples. Concentrations of the four metals nickel $(\mathrm{Ni})$, chromium $(\mathrm{Cr})$, mercury $(\mathrm{Hg})$, and lead $(\mathrm{Pb})$ were measured.

\section{Sampling}

Thunnus tonggol and Liza klunzingeri samples were selected from the town market, and Pleuronectiforme samples were caught from the sea and transferred to the Persian Gulf and Oman Sea Ecological Research Laboratory. The standard length of the fish after cleaning was measured by biometric boards, and their weight was measured by a laboratory scale with an accuracy of $0.1 \mathrm{~g}$. Fish muscle is not an active site for heavy metal accumulation. In other words, fish muscle compared with other tissue has the lowest concentration of heavy metals (6). Therefore, because of its role in the transfer of heavy metals to the human body, muscle tissue was chosen as the target organ in risk assessment. Samples of 15-20 g of fish muscle tissue were selected and washed once with both municipal and distilled water. They were stored in plastic bags and, after coding, were frozen at $-19^{\circ} \mathrm{C}$.
Sample preparation and device analysis

Samples were prepared according to the Manual of oceanographic observations and pollutant analyses methods (MOOPAM), 1999 method. Heavy metal concentrations $(\mathrm{Cr}, \mathrm{Ni}$, and $\mathrm{Pb})$ were assessed using graphite furnace atomic absorption spectrometry. $\mathrm{Hg}$ concentrations were measured using an atomic absorption spectrometer equipped with a hydride generator. Data quality was checked by analyzing standard reference materials (DORM-2 National Research Council, Canada). Recovery values of collaborative recovery model (CRM) samples were in the range of $95.2 \%-97 \%$.

\section{Statistical analysis}

Data was tested for normality using the Shapiro-Wilk test. Since the data did not show a normal distribution, the Mann-Whitney and Kruskal-Wallis tests were used to compare average heavy metal concentrations in different fish species. The Pearson correlation coefficient was used for normal data to test the correlation between fish length and concentration of heavy metals; for abnormal data, the Spearman correlation coefficient was used. A level of 0.05 was considered significant. All tests were performed by SPSS version 18, and Excel software was used to draw diagrams.

\section{Comparison with guidelines and standards}

Since there is no standard for heavy metals involving fish in Iran, amounts of $\mathrm{Ni}, \mathrm{Cr}, \mathrm{Hg}$, and $\mathrm{Pb}$ in the tested fish were compared with guidelines from the World Health Organization (WHO), FAO, The Joint FAO/WHO Expert Committee Report on Food Additives (JECFA), the European Commission, standards formulated by the American Food and Drug Administration (USFDA), the Ministry of Agriculture, Fisheries, and Food of the United Kingdom (MAFF), and China's national regulations regarding (Table 1).

Estimated daily intake and estimated weekly intake of heavy metals

Based on the method proposed by Fathi et al (23), daily and weekly absorption rates were calculated using equation 1 :

$\mathrm{EWI}=\mathrm{C} \times \mathrm{IR} / \mathrm{BW}$

where estimated weekly intake (EWI) ( $\mu \mathrm{g} / \mathrm{kg}$-week) is the EWI of pollutant; $\mathrm{C}(\mu \mathrm{g} / \mathrm{g})$ is the average concentration of pollutant; IR (g/week) is the amount of food intake; and BW $(\mathrm{kg})$ is the body weight of the consumer.

Table 1. Guidelines of WHO, FAO, JECFA, MAFF, the European Commission, standards formulated by the USFDA, and China's national regulations regarding heavy metals $(\mathrm{mg} / \mathrm{kg})$

\begin{tabular}{|c|c|c|c|c|c|c|}
\hline Codify by & Year & $\mathrm{Ni}$ & $\mathrm{Cr}$ & $\mathrm{Hg}$ & $\mathrm{Pb}$ & References \\
\hline JECFA & 1989 & - & - & 0.5 & 0.5 & (18) \\
\hline Europe Commission(EC) & 2006 & - & - & $0.5-1$ & 0.3 & (18) \\
\hline WHO & 1996 & - & - & - & 2 & (18) \\
\hline FAO & 1983 & - & - & - & 0.5 & (19) \\
\hline USFDA & 1993 & $70-80$ & $12-13$ & - & - & (20) \\
\hline MAFF & 2000 & - & - & 0.3 & 2 & (21) \\
\hline China national regulations & - & - & 0.5 & 0.3 & 1 & $(22)$ \\
\hline
\end{tabular}


Risk assessment

Risk assessment is a process to calculate or estimate the risk for a given population exposed to certain pollutants (24). This risk assessment study investigated the target hazard quotient (THQ) for three groups: children, normal adults (non-fishermen), and fishermen. THQ is defined as the daily intake of pollutants higher than the reference dose. Estimates were based on the method proposed by Yi et al (25) and equation 2:

$\mathrm{THQ}=(\mathrm{EFr} \times \mathrm{EDtot} \times \mathrm{FIR} \times \mathrm{C}) /(\mathrm{RFDo} \times \mathrm{BWa} \times \mathrm{ATn}) \times 10^{-3}$ (2)

where THQ (unitless) is the THQ; EFr (day/year) is the exposure frequency; EDtot (year) is the exposure duration; FIR $(\mathrm{g} / \mathrm{d})$ is the food ingestion rate; $\mathrm{C}(\mu \mathrm{g} / \mathrm{g})$ is the concentration of heavy metals in fish; BWa $(\mathrm{kg})$ is the average body weight of consumers; RFDo $\left(\mu \mathrm{g} \mathrm{g}^{-1} \mathrm{day}^{-1}\right)$ or $\left(\mathrm{mg} \mathrm{kg}^{-1}\right.$ day $\left.^{-1}\right)$ is the reference dose; and ATn (day) is the average time for exposure to non-carcinogens.

A THQ of THQ $<1$ indicates that, based on current consumption rates and current concentrations of pollutants in fish, the consumption of fish has no adverse effects on the health of consumers over a lifetime (26).

EFr: In this study, an exposure frequency of 128 days was considered (7).

EDtot: Exposure time was considered to be 70 years based on life expectancy in Hormozgan province (27).

FIR: Based on the General Department of Fisheries of Hormozghan province, this study used a dose of $50 \mathrm{mg}$ per day (28). This amount was considered to be $20 \mathrm{~g}$ per day for children and 2.4 times more than the normal range for fishermen (29).

The parameter of heavy metal concentrations in fish was extracted from the mean heavy metal concentrations in fish muscle in the present study.

BW: In this study, the average adult weight was considered to be $60 \mathrm{~kg}$, based on a 2009 research in Iran by Hajizadeh et al (30), and child weight was considered to be $33 \mathrm{~kg}$ (29).

RFDo: The USEPA in 2008 determined the reference doses for $\mathrm{Cr}$ and $\mathrm{Ni}$ to be 0.003 and $0.02\left(\mathrm{mg} \mathrm{kg}^{-1} \mathrm{day}^{-1}\right)$, respectively (31), in 2009 determined the reference dose of $0.004\left(\mathrm{mg} \mathrm{kg}^{-1} \mathrm{day}^{-1}\right)$ for $\mathrm{Pb}$ (32), and in 2011 set 0.0003 $\left(\mathrm{mg} \mathrm{kg}^{-1} \mathrm{day}^{-1}\right)$ as the reference dose of $\mathrm{Hg}$. These values were used in calculations in this study (16).

ATn: This time comes from multiplying the number of days during a year and number of years of exposure.

Total THQ of heavy metals in fish or a hazard index (HI) was calculated for each species (16).

Calculating permissible limits of consumption

Since man uses several fish species in his diet, he risks possible contamination from multiple pollutants. Equation 3, given by the USEPA (33), was used to calculate the allowable amount of exposure to multiple contaminants in many fish species:

$\mathrm{CR}_{\text {lim }}=\sum(\mathrm{RfD} . \mathrm{Pm} /(\mathrm{Cmj} \times \mathrm{Pj})) \times \mathrm{BW}$

where, $\mathrm{CR}_{\lim }$ is the allowable amount of fish consumption $(\mathrm{kg} / \mathrm{d})$; RFD is the reference dose $(\mathrm{mg} / \mathrm{kg}-\mathrm{d}) ; \mathrm{Pj}$ is the por- tion of fish species in the food diet; Pm is the portion of contaminants in the food diet; BW is the body weight of consumers $(\mathrm{kg})$; and $\mathrm{Cm}$ is the concentrations of chemical matter (mg/kg).

\section{Results}

The amount of heavy metals in fish

The concentrations of $\mathrm{Ni}, \mathrm{Cr}, \mathrm{Hg}$, and $\mathrm{Pb}$ were tested in the muscles of three species of fish (Thunnus tonggol, Liza klunzingeri, and Pleuronectiformes) collected from the Bandar Abbas coast during the summer and autumn of 2013. Results are listed in Table 2 as mean \pm standard deviation (SD), maximum and minimum amounts according to $\mu \mathrm{g} / \mathrm{g}$ dry weight.

In order of concentration amounts of $\mathrm{Cr}$ and $\mathrm{Ni}$, the fish species are ranked as Thunnus tonggol > Pleuronectiformes > Liza klunzingeri; in terms of the amount of $\mathrm{Hg}$ they are ranked as Pleuronectiformes $>$ Thunnus tonggol $>$ Liza klunzingeri. In terms of contamination levels of $\mathrm{Pb}$ they are ranked as Liza klunzingeri> Pleuronectiformes > Thunnus tonggol.

Statistical analyses indicated a significant difference between the concentrations of $\mathrm{Ni}, \mathrm{Cr}$, and $\mathrm{Pb}$ in the tested fish species $(P<0.05)$.

Correlation between heavy metal concentrations and fish length

The correlation between $\mathrm{Ni}, \mathrm{Cr}, \mathrm{Hg}$, and $\mathrm{Pb}$ concentrations fish length in tested species is shown in Table 3. Table 3 shows that there is no significant correlation between $\mathrm{Ni}, \mathrm{Cr}$, or $\mathrm{Hg}$ and the length of the tested fish species, but there is a strong, significant correlation between $\mathrm{Pb}$ and fish length.

Estimated daily intake and estimated weekly intake of heavy metals

To describe the safe levels of absorption of various pollutants, tolerable daily intake (TDI) and tolerable weekly intake (TWI) values have been determined by the JEC-

Table 2. Mean concentrations and standard deviation of heavy metals $(\mu \mathrm{g} / \mathrm{g}$ dry weight) in three tested fish species

\begin{tabular}{lcccc}
\hline Heavy metals & Fish species & Mean \pm SD & Min. & Max. \\
\hline $\mathrm{Ni}$ & Thunnus tonggol & $0.234 \pm 0.06$ & 0.179 & 0.36 \\
$\mathrm{Cr}$ & Thunnus tonggol & $0.059 \pm 0.03$ & 0.018 & 0.097 \\
$\mathrm{Hg}$ & Thunnus tonggol & $0.083 \pm 0.03$ & 0.065 & 0.151 \\
$\mathrm{~Pb}$ & Thunnus tonggol & $0.003 \pm 0.001$ & 0.0018 & 0.005 \\
$\mathrm{Ni}$ & Pleuronectiformes & $0.184 \pm 0.07$ & 0.118 & 0.36 \\
$\mathrm{Cr}$ & Pleuronectiformes & $0.033 \pm 0.01$ & 0.02 & 0.05 \\
$\mathrm{Hg}$ & Pleuronectiformes & $0.095 \pm 0.003$ & 0.036 & 0.153 \\
$\mathrm{~Pb}$ & Pleuronectiformes & $0.004 \pm 0.002$ & 0.002 & 0.01 \\
$\mathrm{Ni}$ & Liza klunzingeri & $0.116 \pm 0.04$ & 0.081 & 0.232 \\
$\mathrm{Cr}$ & Liza klunzingeri & $0.011 \pm 0.01$ & 0.004 & 0.052 \\
$\mathrm{Hg}$ & Liza klunzingeri & $0.078 \pm 0.003$ & 0.054 & 0.175 \\
$\mathrm{~Pb}$ & Liza klunzingeri & $0.006 \pm 0.003$ & 0.018 & 0.013 \\
\hline
\end{tabular}


Table 3. Correlation between $\mathrm{Ni}, \mathrm{Cr}, \mathrm{Hg}$, and $\mathrm{Pb}$ concentrations and fish length in tested species

\begin{tabular}{|c|c|c|c|c|c|c|c|c|}
\hline \multirow{2}{*}{ Fish type } & \multicolumn{2}{|c|}{$\mathrm{Ni}$} & \multicolumn{2}{|c|}{$\mathrm{Cr}$} & \multicolumn{2}{|c|}{$\mathrm{Hg}$} & \multicolumn{2}{|c|}{$\mathrm{Pb}$} \\
\hline & $\mathbf{R}$ & $\mathbf{P}$ & $\mathbf{R}$ & $\mathbf{P}$ & $\mathbf{R}$ & $\mathbf{P}$ & $\mathbf{R}$ & $\mathbf{P}$ \\
\hline Thunnus tonggol & 0.29 & 0.29 & 0.07 & 0.48 & 0.34 & 0.22 & 0.06 & 0.83 \\
\hline Pleuronectiformes & 0.3 & 0.27 & 0.45 & 0.21 & 0.11 & 0.7 & 0.6 & 0.02 \\
\hline Liza klunzingeri & 0.2 & 0.46 & 0.49 & 0.19 & 0.1 & 0.7 & 0.14 & 0.62 \\
\hline
\end{tabular}

Table 4. EDI ( $\mu \mathrm{g} / \mathrm{kg}$-day) and EWI ( $\mu \mathrm{g} / \mathrm{kg}$-week) for heavy metals

\begin{tabular}{|c|c|c|c|c|c|c|c|c|}
\hline \multirow[t]{2}{*}{ Fish type } & \multicolumn{2}{|c|}{$\mathrm{Ni}$} & \multicolumn{2}{|c|}{$\mathrm{Cr}$} & \multicolumn{2}{|c|}{$\mathrm{Hg}$} & \multicolumn{2}{|c|}{$\mathrm{Pb}$} \\
\hline & EDI & EWI & EDI & EWI & EDI & EWI & EDI & EWI \\
\hline Thunnus tonggol & 0.195 & 1.36 & 0.049 & 0.344 & 0.07 & 0.487 & 0.003 & 0.021 \\
\hline Pleuronectiformes & 0.15 & 1.07 & 0.027 & 0.19 & 0.079 & 0.55 & 0.004 & 0.028 \\
\hline Liza klunzingeri & 0.096 & 0.676 & 0.009 & 0.065 & 0.065 & 0.457 & 0.005 & 0.036 \\
\hline
\end{tabular}

Abbreviations: EDI, Estimated daily intake; EWI, estimated weekly intake.

FA. They are shown as Provisional tolerable daily intake (PTDI) and Provisional tolerable weekly intake (PTWI) because of their temporary nature. PTWI is the maximum amount of a pollutant that a man can ingest during a lifetime without any acceptable risk to his health (16). Weekly and daily intake rates of heavy metals including $\mathrm{Ni}, \mathrm{Cr}$, $\mathrm{Hg}$, and $\mathrm{Pb}$ through the consumption of Thunnus tonggol, Liza klunzingeri, and Pleuronectiformes were calculated in micrograms per day and micrograms per week, respectively. The results are given in Table 4.

\section{Result of THQ values}

In the present study, THQ was calculated for each of the heavy metals $(\mathrm{Ni}, \mathrm{Cr}, \mathrm{Hg}$, and $\mathrm{Pb})$ in three fish species (Thunnus tonggol, Liza klunzingeri, and Pleuronectiformes) and for three different groups of people (children, normal adults, and fishermen). The results are given in Table 5. It is to be noted that results are unitless.

Because of the possibility of interference and intensification of the effects of heavy metals, the HI was calculated for $\mathrm{Ni}, \mathrm{Cr}, \mathrm{Hg}$, and $\mathrm{Pb}$ in three species (Thunnus tonggol, Liza klunzingeri, and Pleuronectiformes), and the results are shown in Figure 1.

The lowest and highest HIs were associated with the Liza klunzingeri and Pleuronectiformes species, respectively. The maximum HI was seen in the fishermen group, and the lowest was in the category of children.

\section{Calculating the permissible limit of consumption}

The consumers of three different types of fish were divided into seven groups (Thunnus tonggol consumers, Liza klunzingeri consumers, Pleuronectiformes consumers, Thunnus tonggol and Liza klunzingeri consumers, Thunnus tonggol and Pleuronectiformes consumers, Liza klunzingeri and Pleuronectiformes consumers, and consumers of all three species). Permissible intake limits were calculated for the various consumers groups considering the degree of heavy metal contamination from fish consumption for children and adult groups. The results are given in Table 5. It was necessary to determine the proportion of each species in the diet of each consumer group in which members consume two or three species. The ratio of each fish species in the diet was determined based on information regarding consumption. These results are given in Table 6.

Maximum allowable levels of fish consumption belonged to the Liza klunzingeri fish and for adults and children were 7.32 and $4.02 \mathrm{~kg} / \mathrm{d}$, respectively. Minimum allowable levels of fish consumption belonged to the Thunnus tonggol fish and were 4 and $2.2 \mathrm{~kg} / \mathrm{d}$, respectively.

\section{Discussion}

Heavy metal concentrations

Various concentrations of heavy metals ranging widely from 0.0018 to 0.36 were observed in fish muscle tissue. In order of $\mathrm{Cr}$ and $\mathrm{Ni}$ concentrations, the fish species are classified as: Thunnus tonggol > Pleuronectiformes > Liza klunzingeri; in order of $\mathrm{Hg}$ concentrations, they are ranked as Pleuronectiformes > Thunnus tonggol > Liza

Table 5. THQ values for heavy metals in three fish species for children, normal adults, and fishermen

\begin{tabular}{llccc}
\hline Heavy & Fish species & \multicolumn{3}{c}{ THQ } \\
\cline { 3 - 5 } metals & & Children & Adults & Fishermen \\
\hline $\mathrm{Ni}$ & Thunnus tonggol & 0.0025 & 0.0034 & 0.0082 \\
$\mathrm{Cr}$ & Thunnus tonggol & 0.0042 & 0.0057 & 0.014 \\
$\mathrm{Hg}$ & Thunnus tonggol & 0.0592 & 0.0814 & 0.19 \\
$\mathrm{~Pb}$ & Thunnus tonggol & 0.0002 & 0.0002 & 0.0005 \\
$\mathrm{Ni}$ & Pleuronectiformes & 0.002 & 0.0027 & 0.006 \\
$\mathrm{Cr}$ & Pleuronectiformes & 0.0023 & 0.0032 & 0.008 \\
$\mathrm{Hg}$ & Pleuronectiformes & 0.067 & 0.092 & 0.21 \\
$\mathrm{~Pb}$ & Pleuronectiformes & 0.0002 & 0.0003 & 0.0008 \\
$\mathrm{Ni}$ & Liza klunzingeri & 0.0012 & 0.0017 & 0.0041 \\
$\mathrm{Cr}$ & Liza klunzingeri & 0.0008 & 0.0011 & 0.0026 \\
$\mathrm{Hg}$ & Liza klunzingeri & 0.055 & 0.073 & 0.19 \\
$\mathrm{~Pb}$ & Liza klunzingeri & 0.0003 & 0.0005 & 0.0011 \\
\hline
\end{tabular}

Abbreviations: THQ, target hazard quotient. 


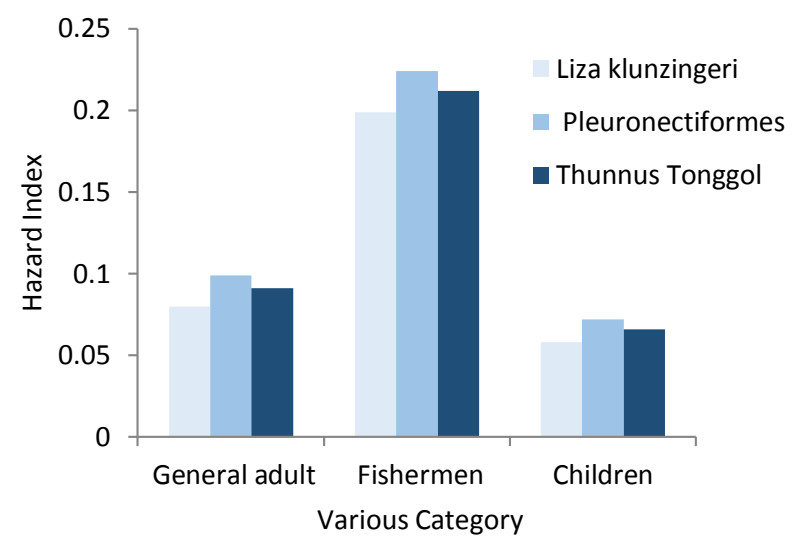

Figure 1. HI of heavy metals in three species (Thunnus tonggol, Liza klunzingeri, and Pleuronectiformes).

klunzingeri. In order of contamination levels of $\mathrm{Pb}$, the fish species are ranked as Liza klunzingeri > Pleuronectiformes > Thunnus tonggol.

Thunnus tonggol was larger than the two other tested species of fish and average concentrations of $\mathrm{Ni}$ and $\mathrm{Cr}$ were higher in it than in the other two species (Liza klunzingeri and Pleuronectiformes). One reason for the higher contamination of Thunnus tonggol by $\mathrm{Cr}$ and $\mathrm{Ni}$ may be the result of their feeding patterns. Indeed, this species feeds on shrimp, crabs, and small fish and has a wider food chain than the other two species.

Pleuronectiformes was smaller than Thunnus tonggol, but its average concentration of $\mathrm{Hg}$ was higher. Maximum accumulation and storage of heavy metals occurred in benthic fish eaters, plankton eaters, and carnivores. The high concentration of $\mathrm{Hg}$ in Pleuronectiformes could be attributed to this reason.

The concentration of all studied heavy metals except $\mathrm{Pb}$ was lower in Liza klunzingeri than in the two other species. Heavy metals accumulation was lower in phytophagous species than in carnivorous species (34); the Liza klunzingeri species is small and phytophagous, and that could be a reason for its low heavy metals concentration. Statistical analysis showed a significant difference between the concentrations of $\mathrm{Ni}, \mathrm{Cr}$, and $\mathrm{Pb}$ in the tested fish species $(P<0.05)$.

Comparison of results with guidelines and standards The heavy metal concentrations of $\mathrm{Ni}, \mathrm{Cr}, \mathrm{Hg}$, and $\mathrm{Pb}$ in three species of fish (Thunnus tonggol, Liza klunzingeri, and Pleuronectiformes) tested in this study were lower than the limits recommended by the guidelines of WHO, FAO, JECFA, the European Commission, and the standards formulated by the USFDA, the MAFF, and China's national regulations, which are shown in Table 1.

Comparison with other studies

The heavy metal concentrations for the species of Thunnus tonggol, Liza klunzingeri, and Pleuronectiformes in this study were compared with other studies (Table 7). Comparing the data in Tables 2 and 7 indicates that concentrations of $\mathrm{Ni}, \mathrm{Cr}$, and $\mathrm{Pb}$ were higher in fish of Lake Taihu, China and Tagus Estuary in Portugal than the fish in this study. The $\mathrm{Cr}$ concentration in fish of rivers in Italy placed in the Cr range in this study, but concentrations of $\mathrm{Hg}$ and $\mathrm{Pb}$ were higher than the range of this study.

Several factors are involved in the accumulation of met-

Table 6. Contribution of each species in food diet and permitted consumption levels for each of the seven groups and three new cases.

\begin{tabular}{|c|c|c|c|c|c|}
\hline \multirow{2}{*}{ Consumer category } & \multicolumn{3}{|c|}{ The ratio of species in food diet } & \multicolumn{2}{|c|}{ Consumption permitted levels (kg per day) } \\
\hline & Thunnus tonggol & Pleuronectiformes & Liza klunzingeri & Children & Adults \\
\hline Just Thunnus tonggol & 1 & 0 & 0 & 2.2 & 4 \\
\hline Just Liza klunzingeri & 0 & 1 & 0 & 2.8 & 5.09 \\
\hline Just Pleuronectiformes & 0 & 0 & 1 & 4.02 & 7.32 \\
\hline $\begin{array}{l}\text { Thunnus tonggol and Liza } \\
\text { klunzingeri }\end{array}$ & 0.7 & 0.3 & 0 & 2.66 & 4.84 \\
\hline $\begin{array}{l}\text { Thunnus tonggol and } \\
\text { Pleuronectiformes }\end{array}$ & 0.6 & 0 & 0.4 & 2.9 & 5.27 \\
\hline $\begin{array}{l}\text { Liza klunzingeri and } \\
\text { Pleuronectiformes }\end{array}$ & 0 & 0.4 & 0.6 & 3.55 & 6.46 \\
\hline All tree species & 0.5 & 0.2 & 0.3 & 3.05 & 5.55 \\
\hline
\end{tabular}

Table 7. Comparison of measured heavy metal concentrations in tested fish with concentrations taken from the literature ( $\mu \mathrm{g} / \mathrm{g})$

\begin{tabular}{lcccc}
\hline Sampling site & $\mathbf{N i}$ & $\mathbf{C r}$ & $\mathrm{Pb}$ & $\mathrm{Hg}$ \\
\hline Lake Taihu, China & $0.64-2.59$ & $0.7-0.98$ & $1.73-12.87$ & - \\
Tagus estuary in Portugal & $3.12-14.35$ & $0-0.56$ & $8.55-46.47$ & $(11)$ \\
Italy rivers & - & 0.04 & 0.04 & $(35)$ \\
Shadegan wetland, Iran & $2.59-98.64$ & $0.0-0.7$ & $1.37-12.87$ & $(12)$ \\
Moses estuary in Iran & 2.35 & 48.14 & 1.32 & $(36)$
\end{tabular}


als in different organs of fish, such as age, length, weight, gender, food habitat, ecological demands, metal concentrations in water and sediment, fish shelf life in contaminated environments, the fishing season, and the physical and chemical properties of water (17). Therefore, one cannot explain why the results of other studies are higher than those of this study. One major reason could be the noted differences, such as the feeding habits of the studied species and contamination in their living environments.

Estimated daily and weekly intake

Guidelines of the JECFA in 2010 designated 1.75 and 0.35 ( $\mu \mathrm{g} / \mathrm{kg}$-week) as PTWI for $\mathrm{Pb}$ and $\mathrm{Hg}$ levels, respectively (7). In 2004, the PTWI for Ni was determined to be 35 ( $\mu \mathrm{g} / \mathrm{kg}$-week) (6). Recommended PTWI amounts of Ni and $\mathrm{Pb}$ are higher than the calculated weekly absorption rate in this study. In the case of $\mathrm{Hg}$, however, it is lower.

\section{Risk assessment}

The THQ of tested metals in the studied species and for different groups (children, normal adults, and fishermen) was less than 1 . Thus, the danger caused by each of the studied metals alone does not threaten the health of consumers. The results of this study are consistent with those of Tao et al (29) in 2012 in Lake Taihu, China and the results of Taweel et al (38) in 2013 in Langat River and Engineering Lake, Malaysia. In contrast to the results of this study, Krishna et al reported in 2014 a THQ higher than 1 for $\mathrm{Pb}, \mathrm{Cr}$, and $\mathrm{Hg}$ in fish from the Machilipatnam coast in India (14). A HI of less than 1 was achieved in each of the studied species. Therefore, the current consumption rate of each species poses no danger to consumer health (considering the interference and resonance effects of the studied metals).

\section{Conclusion}

The order of mean heavy metal concentrations in fish is $\mathrm{Ni}>\mathrm{Hg}>\mathrm{Cr}>\mathrm{Pb}$. The highest mean concentrations of $\mathrm{Ni}$ and $\mathrm{Cr}$ were obtained in Thunnus tonggol. The highest mean concentration of $\mathrm{Hg}$ was obtained in Pleuronectiformes, and the highest mean concentration of $\mathrm{Pb}$ was obtained in Liza klunzingeri. There was a significant difference between the average concentrations of similar metals (except $\mathrm{Hg}$ ) in different species. Only levels of $\mathrm{Pb}$ were significantly associated with the length of the Liza klunzingeri species. Obtained estimations of daily and weekly intakes (except for $\mathrm{Hg}$ ) were much lower than the PTDI and PTWI. The THQ of all tested metals in the studied species and the HI of all three species were less than 1 . Therefore, consumption of the studied fish has no health risk for consumers. The consumption of up to $4 \mathrm{~kg} / \mathrm{d}$ of Thunnus tonggol and $7.32 \mathrm{~kg} / \mathrm{d}$ of Liza klunzingeri causes no health problems for general adult consumers.

\section{Acknowledgments}

This research is derived from a Master's thesis and has been approved to be conducted at the Environmental Health Engineering Research Center. It was sponsored by the Vice-Chancellor for Research and Technology of Kerman University of Medical Sciences and supported by the Persian Gulf and Oman Sea (Bandar Abbas) Ecological Research Institute.

\section{Ethical issues}

The authors hereby certify that all data collected during the study is as stated in this manuscript, and no data from the study has been or will be published elsewhere separately.

\section{Competing interests}

The authors declare that they have no competing interests.

\section{Authors' contributions}

All authors contributed equally and were involved in the design of the study, data collection, and article approval.

\section{References}

1. Foladifard R, Ebrahimi AA. Efficiency study of nickel (II) and cadmium (II) biosorption by powder of waste activated sludge from aqueous solutions. Iranian Journal of Health and Environment 2010; 3(4): 419-30. [In Persian].

2. Cruz GC, Din Z, Feri CD, Balaoing AM, Marie Gonzales E, Navidad HM. Analysis of toxic heavy metals (arsenic, lead, and mercury) in selected infant formula milk commercially available in the Philippines by AAS. E-International Scientific Research Journal 2009; 1(1): 40-51.

3. Askari SaryA, Khodadadi M, Mohammadi M. Concentration of heavy metal $(\mathrm{Cd}, \mathrm{Pb}, \mathrm{Ni}, \mathrm{Hg})$ in muscle, gill and liver tissues of Barbus xanthopterus in Karoon River. Iranian Scientific Fisheries Journal 2010; 19(4): 97-106.

4. Squadrone S, Prearo M, Brizio P, Gavinelli S, Pellegrino M, Scanzio T, et al. Heavy metals distribution in muscle, liver, kidney and gill of European catfish (Silurus glanis) from Italian Rivers. Chemosphere 2013; 90(2): 358-65.

5. Taghavi Jelodar H, Fazli H, Salman Mahiny A. Study on heavy metals (chromium, cadmium, cobalt and lead) concentration in three pelagic species of Kilka (Genus Clupeonella) in the southern Caspian Sea. Iranian Journal of Fisheries Sciences 2016; 15(1): 567-74.

6. Elnabris KJ, Muzyed SK, El-Ashgar NM. Heavy metal concentrations in some commercially important fishes and their contribution to heavy metals exposure in Palestinian people of Gaza Strip (Palestine). Journal of the Association of Arab Universities for Basic and Applied Sciences 2013; 13(1): 44-51.

7. Mortazavi MS, Sharifian S, Aghajari N. Risk estimation of heavy metals from consumption of silver pomfred and tiger tooth croaker in hormozgan province. Iranian Scientific Fisheries Journal 2013; 22(2): 127-36.

8. Sen I, Shandil A, Shrivastava VS. Study for determination of heavy metals in fish species of the River Yamuna (Delhi) by inductively coupled plasma-optical emission spectroscopy (ICP-OES). Advances in Applied Science Research 2011; 2(2): 161-6.

9. Ahmad AK, Sarah AA. Human health risk assessment of 
heavy metals in fish species collected from catchments of former tin mining. International Journal of Research Studies in Science, Engineering and Technology 2015; 2(4): 9-21.

10. Koki IB, Bayero AS, Umar A, Yusuf S. Health risk assessment of heavy metals in water, air, soil and fish. African Journal of Pure and Applied Chemistry 2015; 9(11): 204-10.

11. Zeng J, Yang L, Wang X, Wang WX, Wu QL. Metal accumulation in fish from different zones of a large, shallow freshwater lake. Ecotoxicol Environ Saf 2012; 86: $116-24$

12. Mortazavi A, Hatamikia M, Bahmani M, Hassanzadazar H. Heavy metals (mercury, lead and cadmium) determination in 17 species of fish marketed in Khorramabad city, West of Iran. Journal of Chemical Health Risks 2016; 6(1): 41-8.

13. Olusola JO, Festus AA. Assessment of heavy metals in some marine fish species relevant to their concentration in water and sediment from coastal waters of Ondo State, Nigeria. Journal of Marine Science: Research \& Development 2015; 5(2): 1-6.

14. Krishna PV, Rao KM, Swaruparan IV, Rao DS. Heavy metals concentration in fish mugil cephalus from machilipatnam coast and possible health risks to fish consumers. British Biotechnology Journal 2014; 4(2): 126-35.

15. Akoto O, Bismark Eshun F, Darko G, Adei E. Concentrations and health risk assessments of heavy metals in fish from the Fosu Lagoon. Int J Environ Res 2014; 8(2): 403-10.

16. Bhupander K, DP M. Assessment of human health risk for arsenic, copper, nickel, mercury and zinc in fish collected from tropical wetlands in India. Advances in Life Science and Technology 2011; 2: 13-25.

17. Mashroofeh A, Bakhtiari AR, Pourkazemi M. Evaluation of cadmium, vanadium, nickel and zink concentrations in different tissues of beluga and stellate sturgeon and risk assessment regarding consuming their muscle tissue in south Caspian Sea. J Mazandaran Univ Med Sci 2012; 22(96): 90-7. [In Persian].

18. Al Sayegh Petkovšek S, Mazej Grudnik Z, Pokorny B. Heavy metals and arsenic concentrations in ten fish species from the Šalek lakes (Slovenia): assessment of potential human health risk due to fish consumption. Environ Monit Assess 2012; 184(5): 2647-62.

19. Sivaperumal P, Sankar TV, Viswanathan Nair PG. Heavy metal concentrations in fish, shellfish and fish products from internal markets of India vis-a-vis international standards. Food Chem 2007; 102(3): 612-20.

20. Rahman MS, Molla AH, Saha N, Rahman A. Study on heavy metals levels and its risk assessment in some edible fishes from Bangshi River, Savar, Dhaka, Bangladesh. Food Chem 2012; 134(4): 1847-54.

21. Yohannes YB, Ikenaka Y, Nakayama SM, Saengtienchai A, Watanabe K, Ishizuka M. Organochlorine pesticides and heavy metals in fish from Lake Awassa, Ethiopia: insights from stable isotope analysis. Chemosphere 2013; 91(6): 857-63

22. Zhang Z, He L, Li J, Wu Z. Analysis of heavy metals of muscle and intestine tissue in fish - in Banan section of Chongqing from Three Gorges Reservoir, China. Polish J Environ Stud 2007; 16(6): 949-958.

23. Fathi HB, Othman MS, Mazlan AG, Arshad A, Amin $\mathrm{SM}$, Simon KD. Trace metals in muscle, liver and gill tissues of marine fishes from Mersing, Eastern Coast of Peninsular Malaysia: concentration and assessment of human health risk. Asian Journal of Animal and Veterinary Advances 2013; 8(2): 227-236.

24. Arizhibowa F. A human health risk assessment of heavy metal bioaccumulation in Nile Tilapia Oreochromis niloticus from Lake Chivero, Zimbabwe [Thesis]. Zimbabwe: University of Zimbabwe; 2011.

25. Yi Y, Yang Z, Zhang S. Ecological risk assessment of heavy metals in sediment and human health risk assessment of heavy metals in fishes in the middle and lower reaches of the Yangtze River basin. Environ Pollut 2011; 159(10): 2575-85.

26. Hosseini SM, Mirghaffari N, Mahboobi Soofiani N, Hosseini SV. Risk assessment of mercury due to consumption of kutum of the Caspian Sea (Rutilus frisii kutum) in Mazandaran province. Iranian Journal of Natural Resources 2011; 64(3): 243-57. [In Persian].

27. Khosravi A, Najafi F, Rahbar MR, Motlagh MI, Kabir MJ. Landscape indicators of health in the Islamic Republic Iran.Tehran: Department of Health and Medical Education, Islamic Republic of Iran; 2009.

28. GDOFHP. Determination of per capita consumption of aquatic in level Hormozgan province. General Directorate of Fisheries Hormozgan province: coast sea researchers consulting engineers; 2010. http://www.hpf. ir/.

29. Tao Y, Yuan Z, Xiaona H, Wei M. Distribution and bioaccumulation of heavy metals in aquatic organisms of different trophic levels and potential health risk assessment from Taihu lake, China. Ecotoxicol Environ Saf 2012; 81: 55-64.

30. Hajizadeh S, Faghihzadeh S, Khaksari M, Boskabadi M, Pejhan A, Rostampour M, et al. Measurement of vital pulmonary parameters of sample iranian populations to determine reference equations for estimation of these parameters. Knowledge \& Health 2009; 4(1): 1-7. [In Persian].

31. Zhao S, Feng C, Quan W, Chen X, Niu J, Shen Z. Role of living environments in the accumulation characteristics of heavy metals in fishes and crabs in the Yangtze River Estuary, China. Mar Pollut Bull 2012; 64(6): 1163-71.

32. Zhuang P, Li ZA, McBride MB, Zou B, Wang G. Health risk assessment for consumption of fish originating from ponds near Dabaoshan mine, South China. Environ Sci Pollut Res Int 2013; 20(8): 5844-54

33. USEPA. Guidance for Assessing Chemical Contaminant Data for Use in Fish Advisories Volume 2 : Risk Assessment and Fish Consumption Limits. Washington, DC: USEPA; 2000

34. Beheshti M, Askari Sari A, Velayatzadeh M. Assessment of heavy metals concentration of fish (Liza abu) in Karoon River, Khouzestan province. Water and wastewater. 2012; 3: 125-33 .[In Persian].

35. Caçador I, Costa JL, Duarte B, Silva G, Medeiros 
JP, Azeda C, et al. Macroinvertebrates and fishes as biomonitors of heavy metal concentration in the Seixal Bay (Tagus estuary): Which species perform better? Ecol Indic 2012; 19: 184-90.

36. Hosseini Alhashemi A, Sekhavatjou MS, Hassanzadeh Kiabi B, Karbassi AR. Bioaccumulation of trace elements in water, sediment, and six fish species from a freshwater wetland, Iran. Microchem J 2012; 104: 1-6.

37. Parvaneh M, Khaivar N, Nikpour Y, Nabavi SM. Heavy metals $(\mathrm{Hg}, \mathrm{Cd}, \mathrm{Pb}, \mathrm{Ni}, \mathrm{Cu})$ concentrations in Euryglossa orientalis and sediments from Khur-e-Musa Creek in Khuzestan Province. Iranian Scientific Fisheries Journal 2011; 20(2): 17-26. [In Persian].

38. Taweel A, Shuhaimi-Othman M, Ahmad AK. Assessment of heavy metals in tilapia fish (Oreochromis niloticus) from the Langat River and Engineering Lake in Bangi, Malaysia, and evaluation of the health risk from tilapia consumption. Ecotoxicol Environ Saf 2013; 93: 45-51. 